\title{
Placodont remains (Sauropsida, Sauropterygia) from the Triassic of Hungary (Transdanubian Range and Villány Mountains)
}

\author{
Kinga Gere ${ }^{1} \cdot$ Torsten M. Scheyer $^{2}$ • László Makádi ${ }^{3}$ • Attila Ősi ${ }^{1,4}$
}

Received: 18 October 2019 / Revised: 31 January 2020 / Accepted: 6 April 2020 / Published online: 27 August 2020

(C) The Author(s) 2020

\begin{abstract}
New placodont remains from the Triassic of Hungary are described here. They come from two different tectonic units: the Transdanubian Range Unit representing Alpine type sedimentary basins and the Villány-Bihar Unit that was part of the southern passive margin of the European Plate during the Triassic. The fossils came from four stratigraphic levels with the oldest specimen, a maxilla fragment found in the upper Anisian of Forrás Hill, near Felsőörs (Transdanubian Range). Based on dental morphology, the specimen is referred to here as Paraplacodus broilii. This site is similar in age to the Monte San Giorgio (Switzerland and Italy) locality. A Carnian occurrence of placodonts from this tectonical unit is a dentary fragment and two isolated teeth referred to here as Placochelys placodonta. The youngest specimen from this unit is a placochelyid tooth fragment from the Rhaetian of the Keszthely Mountains (Transdanubian Range). The richest assemblage of new placodont remains is from the Ladinian of the Villány Mountains, southern Hungary. Cranial elements are referred to here as Cyamodus sp. Teeth from this site are similar to that of Cyamodus sp. described from Slovenia, and both assemblages are among the last occurrences of the genus in the European Triassic. The Villány site is considered as a gap locality because of the rarity of Ladinian placodont occurrences in the German-Alpine sedimentary basins.
\end{abstract}

Keywords Paraplacodus $\cdot$ Cyamodus $\cdot$ Placochelys $\cdot$ Anisian $\cdot$ Ladinian $\cdot$ Carnian

\section{Introduction}

Bones and teeth of placodont reptiles are relatively frequent fossils of Middle to Late Triassic marine vertebrate sites, and this is also the case in the Carpathian region. The first placodont remains in Hungary were found by D. Laczkó in the Upper Triassic of Jeruzsálem Hill on the outskirts of the town of Veszprém (Bakony Mountains, Transdanubian Range) in 1899. That year has been traditionally accepted as the date of finding a partial skeleton (later described as the

Kinga Gere

gere.kinga92@gmail.com

1 Department of Paleontology, Eötvös Loránd University, Pázmány Péter sétány $1 / \mathrm{C}$, Budapest 1117 , Hungary

2 Paläontologisches Institut und Museum, Universität Zürich, Karl Schmid-Strasse 4, 8006 Zurich, Switzerland

3 Mining and Geological Survey of Hungary, Stefánia út 14, Budapest 1143, Hungary

4 Hungarian Natural History Museum, Ludovika tér 2, Budapest 1083, Hungary holotype of Placochelys), but this has been questioned recently and 1901 suggested instead as a result of extensive and thorough research of Bontó (2019). The fossil material consisted of a complete skull and an articulated mandible, some vertebrae (which are mainly cervicals), ribs, pectoral and pelvic girdle elements, femur, humerus, metatarsals and a phalanx, as well as parts of the dorsal dermal armour (holotype, placed in the collection of the Royal Hungarian Geological Institute) (Jaekel 1901). During further excavations, D. Laczkó and his colleagues found another, dorsoventrally compressed fragmentary skull (paratype skull, donated to the Museum für Naturkunde Berlin) (Jaekel 1902a), as well as isolated teeth and a coracoid, supposedly originating from a third (or more) individual (Jaekel 1907) (placed in the collection of the Royal Hungarian Geological Institute). Rieppel (2001) refers to Westphal (1975) in stating that the large part of postcranial elements were lost during World War II, but there are some casts of the femur and humerus in the Natural History Museum of London. Otto Jaekel (1902b) described the Hungarian remains as Placochelys placodonta Jaekel, $1902 \mathrm{~b}$, and this has been considered the most famous fossil of Hungary. He made detailed anatomical descriptions of the 
incompletely prepared holotype skull and mandible, which was later studied and redescribed, among others, by Huene (1931) and Rieppel (2001) in its fully prepared condition. Furthermore, detailed studies followed on the dermal armour (Jaekel 1902b, 1907; Kormos 1917; Rieppel 2002a) and on the reconstruction of the musculature (Rieppel 2002b). However, some specimens collected from the same beds were never published.

In 1908, L. Lóczy collected numerous (mainly invertebrate) fossils from the Upper Triassic beds (NorianRhaetian) of the Akasztó Hill near the village of Rezi (Keszthely Mountain, Transdanubian Range). Among this material, there is a fragmentary placodont tooth that has been published as Placochelys (?) sp. by Böckh and Lóczy (1912), who, in turn, referred to Jaekel's personal communication. Though this specimen was figured, a detailed description was not provided (Böckh and Lóczy 1912).

Chronologically, the next discovery of placodonts in the country is a mandible fragment from the Middle Triassic beds of the Balaton Highland collected by an amateur collector. The specimen is of great importance because, since the discovery of Placochelys in Veszprém, no Triassic vertebrate fossils have been published from this part of the Transdanubian Range.

In 2012, fossiliferous beds were discovered at an artificial outcrop (a construction site) within the town of Villány on the eastern slope of the Somssich Hill (Villány Mountains). This site is rich in Middle Triassic (Ladinian) vertebrates, such as chondrichthyan and osteichthyan fishes (Paleobates, Lissodus, Gyrolepis, Severnichthys), sauropterygian (Eosauropterygians, placodonts) and archosauromorph (Tanystropheus) reptiles (Ösi et al. 2013; Segesdi et al. 2017; Szabó et al. 2019). The first, isolated placodont teeth have been described previously as cf. Cyamodus sp. (Ösi et al. 2013). In the last 6 years, however, new remains, such as skull and dermal armour fragments, vertebrae and a limb bone, have been found, which greatly expand our knowledge on the placodont fauna of the northern Tethyan margin.

The aim of the present study is to describe the still unpublished and newly discovered placodont fossils from Hungary and to discuss their palaeobiogeographic and biostratigraphic significance.

\section{Material and methods}

Placodont fossils collected in Hungary from four different localities of two tectonic units and four stratigraphic levels are described in this paper. The Veszprém, Felsöörs and Rezi localities lie on the Transdanubian Range Unit of the ALCAPA Mega-unit, while the Villány locality is located on the Villány-Bihar Unit of the TISZA Mega-unit (Fig. 1).
The specimens from Villány have been systematically collected during annual field campaigns since the spring of 2012. Most of the remains were found in the Templomhegy Dolomite Member of the Csukma Dolomite Formation by mechanical breakdown of the bone-bearing rocks and during screen-washing of some potential fossiliferous layers (Ösi et al. 2013; Botfalvai et al. 2019). Specimens were prepared mechanically in the laboratory of the Hungarian Natural History Museum and the Department of Paleontology of the Eötvös Loránd University. Cranial and postcranial remains identified from Villány include three skull fragments with teeth, dozens of isolated teeth and tooth fragments, four vertebrae, one limb bone and three isolated and four associated dermal armour fragments. The enamel on most of the teeth is black or dark brown with light yellow or red dentine, and the enamel is usually weathered and cracked. Bones are reddish in colour and generally very fragile, held together by the matrix.

The holotype of Placochelys placodonta from Veszprém was catalogued as Ob.2323 in 1907 at the Royal Hungarian Geological Institute and later also got an additional "type inventory number", Vt.3. However, other Placochelys material collected by Laczkó but obviously not originating from the same individual was also inventoried under the same number for unknown reasons. Moreover, some parts of the holotype, mostly figured by Jaekel (1902a, 1902b), were inventoried decades later, under different inventory numbers: Ob.3268 armour part (inventoried in 1916), Ob.4206 cervical vertebra fragment (1935), Ob.4208 phalanx (1935), Ob.4209 armour natural cast (1935) and possibly Ob.4211 pectoral and pelvic elements (1935). Regardless, the holotype partial skeleton of Placochelys placodonta was well studied and published. The paratype skull (MB.R. 1765) has been also thoroughly documented (e.g. Jaekel 1902a; Rieppel 2001).

However, among the isolated specimens, there are two isolated teeth and a dentary fragment with a tooth (all these three items are catalogued under the same inventory number as the majority of the holotype, Ob.2323) from the same locality and stratigraphic level that have not been published yet. Since the holotype and paratype have their dentitions preserved completely, the isolated teeth and dentary belong to other individual(s) and might bear additional information on feeding ecology. These unpublished specimens of Placochelys have been also collected by Laczkó, and their preparation was completed during the early twentieth century.

The maxilla fragment from Felsőörs was found by private collector P. Tárnoki. The specimen was prepared by him with mechanical preparation tools. The cast of the original specimen is found in the Hungarian Natural History Museum.

Furthermore, the remains from Villány are also housed in the Hungarian Natural History Museum, while the specimens of Placochelys placodonta described here, as well as the 


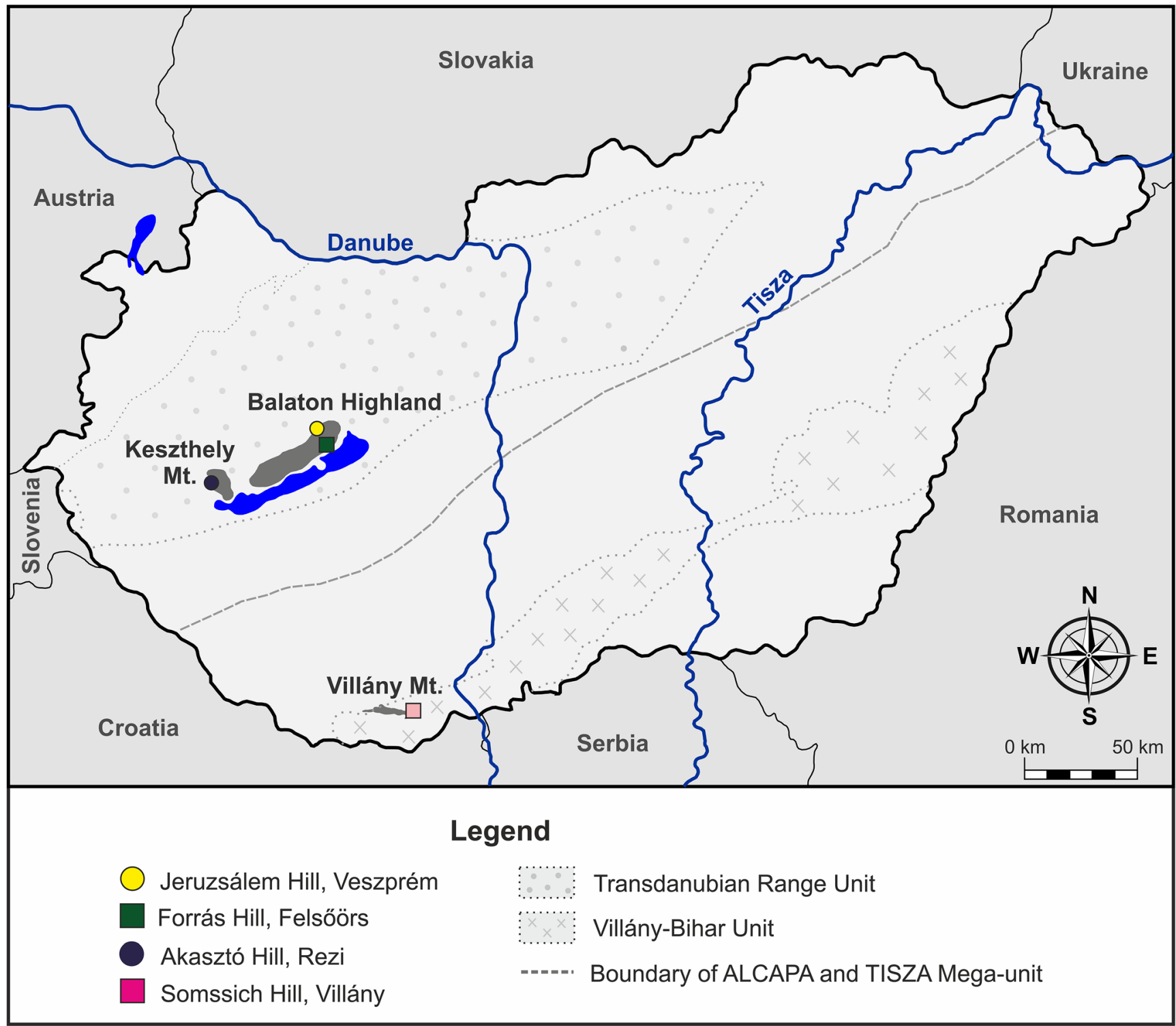

Fig. 1 Location map of the four Hungarian placodont sites

placodont tooth from Rezi, are inventoried in the Mining and Geological Survey of Hungary (formerly the [Royal] Geological Institute of Hungary).

Institutional abbreviations: BSP Bayerische Staatssammlung für Paläontologie und Historische Geologie München; GPIT Geologisch-Paläontologisches Institut, Universität Tübingen; MBFSZ The Mining and Geological Survey of Hungary (originally the Royal Hungarian Geological Institute, later as MÁFI, Hungarian Geological Institute); MB.R. Museum für Naturkunde Berlin; MFSN Museo Friulano di Storia Naturale Udine; MTM Hungarian Natural History Museum; MUPA ATZ El Atance collection, Museo de Paleontología de Castilla-La Mancha, Cuenca; PIMUZ Paläontologisches Institut und Museum, Universität Zürich; SMF Senckenberg
Forschungsinstitut und Naturmuseum Frankfurt; SMNS Staatliches Museum für Naturkunde Stuttgart

\section{Systematic palaeontology, descriptions and comparisons}

Placodontiformes Neenan et al., 2013

Placodontia Cope, 1871

Placodontoidea Nopcsa, 1923

Paraplacodus Peyer, 1931a, 1931b

Paraplacodus broilii Peyer, 1931a, 1931b

Material: maxilla fragment (MTM VER 2019.124.) 


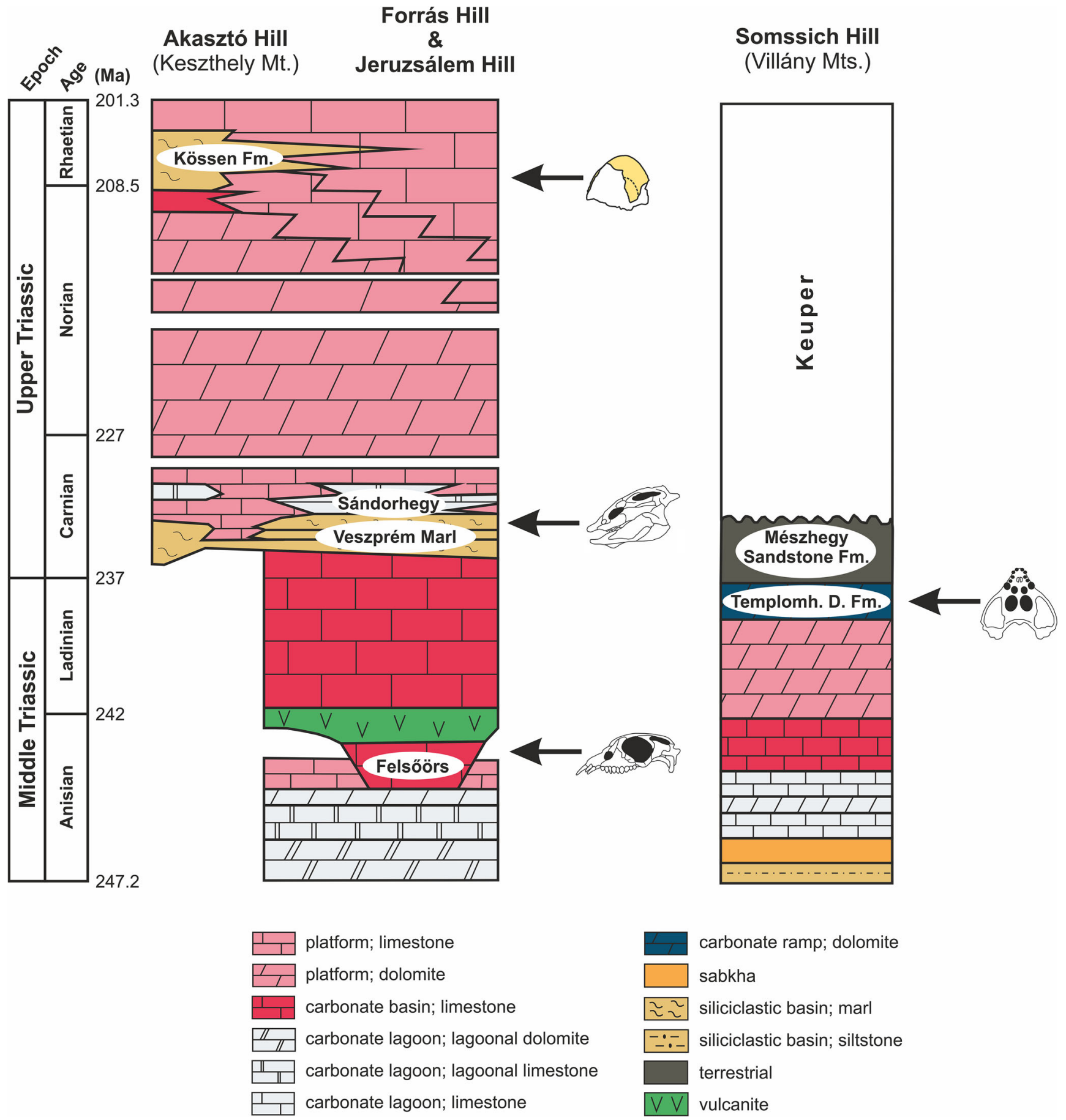

Fig. 2 Stratigraphy and facies succession of the localities. The black arrows show the stratigraphic position of the placodont remains at the Hungarian localities (modified after Haas (2001))

Age: Trinodosus Zone, late Anisian (Middle Triassic) (Vörös et al. 2003)

Locality: Forrás Hill, Felsöörs, Balaton Highland (Transdanubian Range) (Fig. 1)

Stratigraphic range and facies: Felsőörs Limestone Formation Bed 92; well-bedded, laminated brownish grey limestone with interbedding yellow clay (Haas 1985; Vörös et al. 2003; Fig. 2). This sedimentary unit corresponds to a deep water pelagic facies (Haas 1985).

Description: The maxilla fragment is poorly preserved with only a small, ventral part of the lateral wall (anteroposterior length: $2.8 \mathrm{~cm}$ ), and its processes connecting to the surrounding cranial elements are missing (Fig. 3a). It contains four well-preserved teeth with posteriorly increasing size in the 

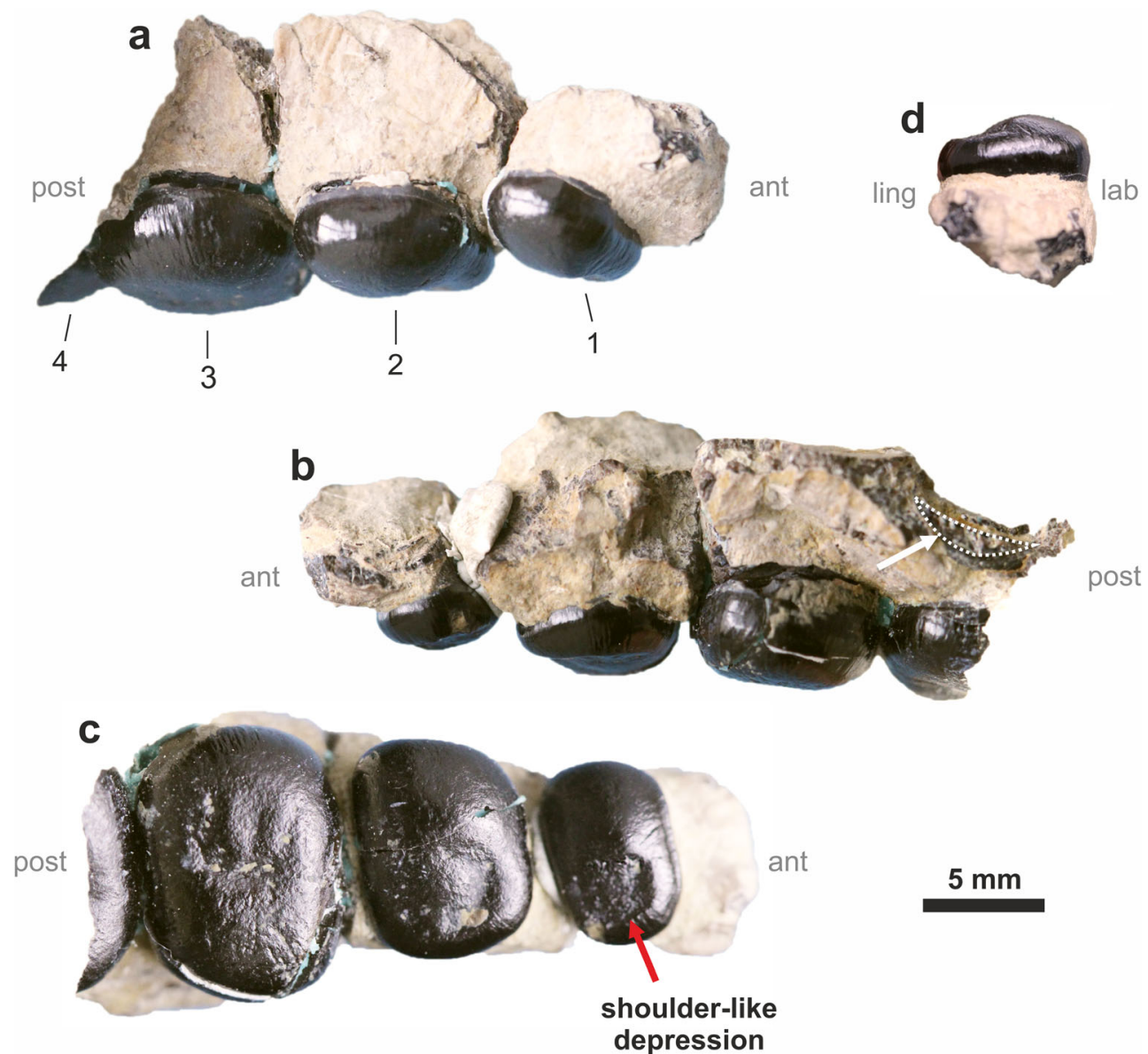

Fig. 3 Paraplacodus broilii maxilla fragment (MTM VER 2019.124.) from the Forrás Hill, Felsőörs, Balaton Highland. a Labial view; b lingual view, the white arrow and the dotted line show the replacement

tooth row. Directly below the fourth functional tooth, a replacement tooth can be observed (Fig. 3b). The enamel is black and shiny. In occlusal view, the teeth have rounded to rectangular shape, and the first tooth is particularly more expanded labiolingually than mesiodistally. The occlusal surface on the first and second teeth is rounded on the labial half of the crown, whereas lingually there is a shoulder-like depression with rough surface (Fig. 3c). The third and fourth teeth lack this depression but have a blunt, worn crown with a mesiodistally directed groove occlusally, though their overall morphology was originally probably similar to that of the first two teeth (Fig. 3c).

Comparisons: There are no useful characters preserved on the bone itself but the fragmentary maxilla can be easily placed within Placodontoidea based on the rectangular shape of the characteristic teeth. The size of the teeth is similar to that of Paraplacodus broilii PEYER 1931a, which has relatively much smaller maxillary teeth than Placodus gigas Agassiz 18331843. The more labiolingually expanded appearance of the teeth is observable in Paraplacodus, while the teeth of Placodus are rather square shaped except for the first tooth. The shoulder-like depression on the lingual side of the teeth in tooth; c occlusal view; $\mathbf{d}$ the first tooth in mesial view. post posterior, ant anterior, ling lingual, lab labial

the Felsöörs specimen is typical for Paraplacodus (Mazin 1989; Rieppel 2000), being more pronounced on the anterior teeth and disappearing gradually with tooth wear posteriorly in the tooth row. However, similar depression can occur on the unworn maxillary teeth of Placodus as well (e.g. SMF R 362), but that is not a shoulder-like depression but rather a triangular surface with three main grooves. In labial view, Paraplacodus teeth have slightly conical shape with large tooth crown height, in contrast to the flatter, lower crowns of Placodus (Mazin 1989; Rieppel 2000). Though the tooth crowns in the Felsöörs maxilla fragment are apparently also flattened like in Placodus, this can be attributed to tooth wear. Thus, the Felsöörs maxilla fragment can be identified as Paraplacodus broilii based on morphological features of its teeth.

Cyamodontoidea Nopcsa, 1923

Cyamodontida Nopcsa, 1923

Cyamodus Meyer, 1863

Cyamodus sp.

Material: maxilla (MTM PAL 2019.227.1.), palatine (MTM PAL 2019.228.1.), dentary (MTM PAL 2019.229.1.), 85 
isolated teeth (MTM VER 2013.15., MTM VER 2019.15. 2019.99.)

Age: late Ladinian (Middle Triassic) (Nagy and Nagy 1976; Török 1998)

Locality: Somssich Hill, Villány, Villány Mountains (Fig. 1) Stratigraphic range and facies: the Templomhegy Dolomite Member of the Csukma Dolomite Formation is characterised by four lithotypes: dolomite; dolomarl; reddish calcareous mudstone and claystone; sandstone (Botfalvai et al. 2019; Fig. 2). This formation corresponds to a subtidal to peritidal zone of an inner ramp depositing in a shelf-lagoon (Török 2000; Haas 2001; Botfalvai et al. 2019).

\section{Description}

Maxilla: The $6.3 \mathrm{~cm}$ long maxilla fragment contains an oval shaped functional, as well as a replacement tooth (Fig. 4a, b). Only the palatal process is preserved, and the other processes for connecting other cranial bones are missing. The length/ width ratio of the functional tooth is $1.3 \mathrm{~cm} / 1.05 \mathrm{~cm}=$ 1.238. The enamel surface is shiny with some shallow pits, but the original ornamentation on its surface cannot be observed. There is a bulge on the middle of the occlusal surface of the 5 -mm-high crown. The replacement tooth is $2-3 \mathrm{~mm}$ thick and has shifted laterally due to diagenetic processes.

Palatine: A left palatine fragment has a 1-cm-high medial margin preserved. This part of the palatine is in the sagittal plane for connection to the right palatine. Ventrally, the bone bears a larger posterior and a smaller anterior tooth, the length/ width ratio of which are $2.5 / 1.6 \mathrm{~cm}=1.56$ and $0.85 / 0.65 \mathrm{~cm}=$ 1.3 , respectively (Fig. $4 \mathrm{c}, \mathrm{d}$ ). The larger tooth is emplaced directly next to the sagittal plane, but the distal part of the tooth turns in labial direction. The smaller tooth is very close to the larger one.

The smaller tooth is oval-shaped with domed tooth crown. It becomes slightly pointed mesiodistally, and its labial side is convex, while the lingual is straight. In the middle of the crown, there is a circular, 3-mm-diameter bulge surrounded by small pits. The enamel is shiny and smooth, and no original ornamentation can be observed.

The larger tooth is much flatter, but its appearance is similar to that of the smaller one. The enamel is shiny; however, the convex labial part of the crown is smooth and worn, while its lingual part is more pitted. Due to diagenetic alteration, the teeth are slightly misplaced from their original positions.

Dentary: A 5.5-cm-long right dentary fragment contains two teeth (Fig. $4 \mathrm{e}-\mathrm{g}$ ). Anteriorly, the dentary preserves only the posterior part of the symphysis and the small portion of bone on which the teeth are sitting.

The smaller tooth has an oval-shaped and domed crown with a $1 / 0.8 \mathrm{~cm}=1.25$ length/width ratio. It bears a $0.2-\mathrm{cm}$ diameter bulge centrally. The enamel surfaces of the teeth are pitted showing the original texture of the crown surface, but in a great part of the crown, this surface is slightly eroded due to feeding. There is a replacement tooth under the smaller tooth, which has a similar appearance and size ratio.

The larger tooth is mesiodistally elongated bean-shaped with the lingual margin being the concave side. The length/ width ratio is $3.2 \mathrm{~cm} / 1.7 \mathrm{~cm}=1.88$. The tooth crown is flat and is covered with pits similar to those on the smaller tooth. These pits can be the traces of the original ornamentation, namely radial striations that have been eroded away.

Isolated teeth: Of the preserved 85 isolated teeth 16 specimens represent one (referred to here as first) morphotype that are flat and more elongated longitudinally (MTM VER 2013.15., MTM VER 2019.27.-2019.42.; Fig. 5a, b). Their length/width ratio varies between $1.8 \mathrm{~cm} / 1.2 \mathrm{~cm}=1.5$ and $3.1 \mathrm{~cm} / 1.8 \mathrm{~cm}=1.7$. These teeth have a bean-like shape with a strongly convex and a slightly concave or in some cases straight side. Tooth crowns become slightly pointed mesiodistally and many pits and radial striations can be observed on the enamel. There is no bulge on the tooth crown. This tooth type can be identified as the last dentary tooth.

Twelve specimens of enlarged teeth can be referred to a second morphotype (MTM VER 2019.15.-2019.26.). These teeth are large and have a slightly oval or circle shape in occlusal view; their length/width ratios are relatively low, e.g. $1.9 / 1.45 \mathrm{~cm}=1.31$ (Fig. $5 \mathrm{c}$ ) or $2.8 / 1.9 \mathrm{~cm}=1.47$ (Fig. $5 \mathrm{~d})$. They are slightly pointed distally and expanded labiolingually. The tooth crown is flat or slightly domed with low height. Macrowear features can be observed almost only on the convex part of the occlusal surface, and the dentine is not exposed. On the well-preserved teeth, a small circle-like bulge in the middle of the crown as well as some fine radial striations can be observed. Furthermore, small shallow radially positioned pits are also present on the enamel. Enamel thickness, as visible at the broken margins, varies between 0.4 and $1.1 \mathrm{~mm}$. In cyamodontoid placodonts, enlarged teeth occur in the last position of the dentary and the palatine (Rieppel 2001). Based on the transversally slightly expanded shape, this second morphotype can be the last (second) palatine tooth because the dentary tooth is relatively narrower transversally.

Thirteen button-like teeth represent the third morphotype (MTM VER 2019.43.-2019.55.; Fig. 5e-h). Their crown has a circular or slightly oval shape in occlusal view, the length/ width ratio varies between $0.5 \mathrm{~cm} / 0.4 \mathrm{~cm}=1.25$ and $1.2 \mathrm{~cm} /$ $0.9 \mathrm{~cm}=1.3$. The crowns are strongly domed, only the worn teeth can be relatively flat. On the well-preserved crowns, a bulge surrounded by small pits can be observed. However, these pits are caused by tooth wear. There are some teeth where the enamel is smooth and there is no ornamentation. It is hard to determine the position of these type of teeth because the maxillary, the anterior palatal and anterior dentary teeth in cyamodontids are usually similar in shape, sometimes having smaller or larger teeth in the lower and upper jaws. 

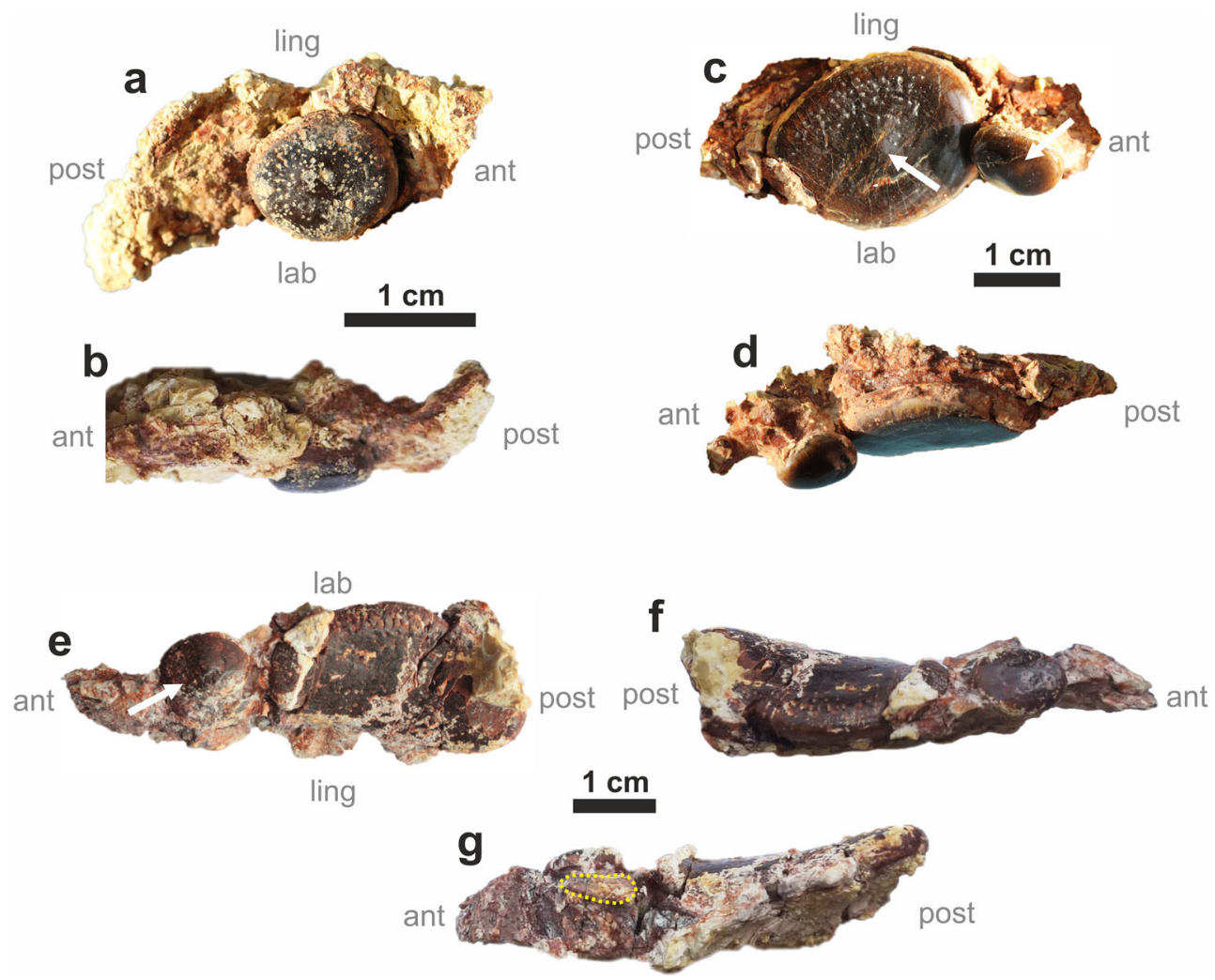

Fig. 4 Associated cranial elements of Cyamodus sp. from Somssich Hill, Villány Mountain. a, b MTM PAL 2019.227.1. maxilla fragment in occlusal (a) and labial view (b). c, d MTM PAL 2019.228.1. palatine fragment in occlusal (c) and labial view (d). e-g MTM PAL 2019.229.1. dentary fragment in occlusal (e), labial (f) and lingual view, where the dotted line shows the replacement tooth $(\mathbf{g})$. The white arrows show the circle bulge on the crown. post posterior, ant anterior, ling lingual, lab labial
In the material, there are five very small fragmentary teeth (MTM VER 2019.56., MTM VER 2019.57., MTM VER 2019.58., MTM VER 2019.59., MTM VER 2019.60.; Fig. $5 \mathrm{i}, \mathrm{j})$. These are slightly triangular in occlusal view and differ from the other morphotypes. They have a more elongated shape; moreover, they are strongly pointed mesially or distally. A bulge can be observed in the middle of the crown similar to the other morphotypes. These forms are probably maxillary or anterior dentary teeth.

The rest of the 87 isolated teeth has not been assigned to either of the abovementioned morphotypes.

Comparisons: The oval shape of the Villány teeth is most similar to those of the Cyamodontoidea (Rieppel 2001; Crofts et al. 2015). The last palatine teeth differ from the much larger and rhomboid palatine teeth of Macroplacus raeticus Schubert-Klempnauer, 1975 (BSP 1967 I 324), and from the subcircular shaped and higher crowned teeth of Protenodontosaurus italicus Pinna, 1990 (MFSN 1819GP). Furthermore, Henodus chelyops Huene, 1936 (GPIT/RE/ 07290) and Parahenodus atancensis Chaves, Ortega et Pérez-García, 2018 (MUPA ATZ0104), are different from those from Villány, in having much smaller, strongly elongated and flattened teeth with a longitudinal central depression
(Reif and Stein 1999; Chaves et al. 2018). The button-like circular shape of maxillary (or first palatine) teeth from Villány are distinguishable from the ovoid shaped teeth of Protenodontosaurus and from the slightly oval shaped teeth of Macroplacus. Furthermore, in these species, no bulge is present centrally on the tooth crown. The Villány maxillary and palatine teeth differ from the more complex crown morphology of Placochelys placodonta and Psephoderma alpinum Meyer, 1858. The palatine teeth of these species are slightly elongated and pointed distally. On the palatine teeth of Psephoderma, there is a broad crescent-shaped depression ornamented labially with deep radial furrows. Teeth of Placochelys preserved in the paratype skull (MB.R. 1765) have two main domed surfaces separated by a deep, narrow groove wrinkled at its mesial and distal ends. The Villány maxillary (or first palatine) teeth are also distinct from those of Psephoderma in being elongated, mesially and distally pointed and ornamented with a depression and deep striations. They also differ from the stockier maxillary teeth of Placochelys that have a crescent-shape depression occlusally.

The Villány teeth are most similar to those of Cyamodus based on their outline and occlusal ornamentation. The last 

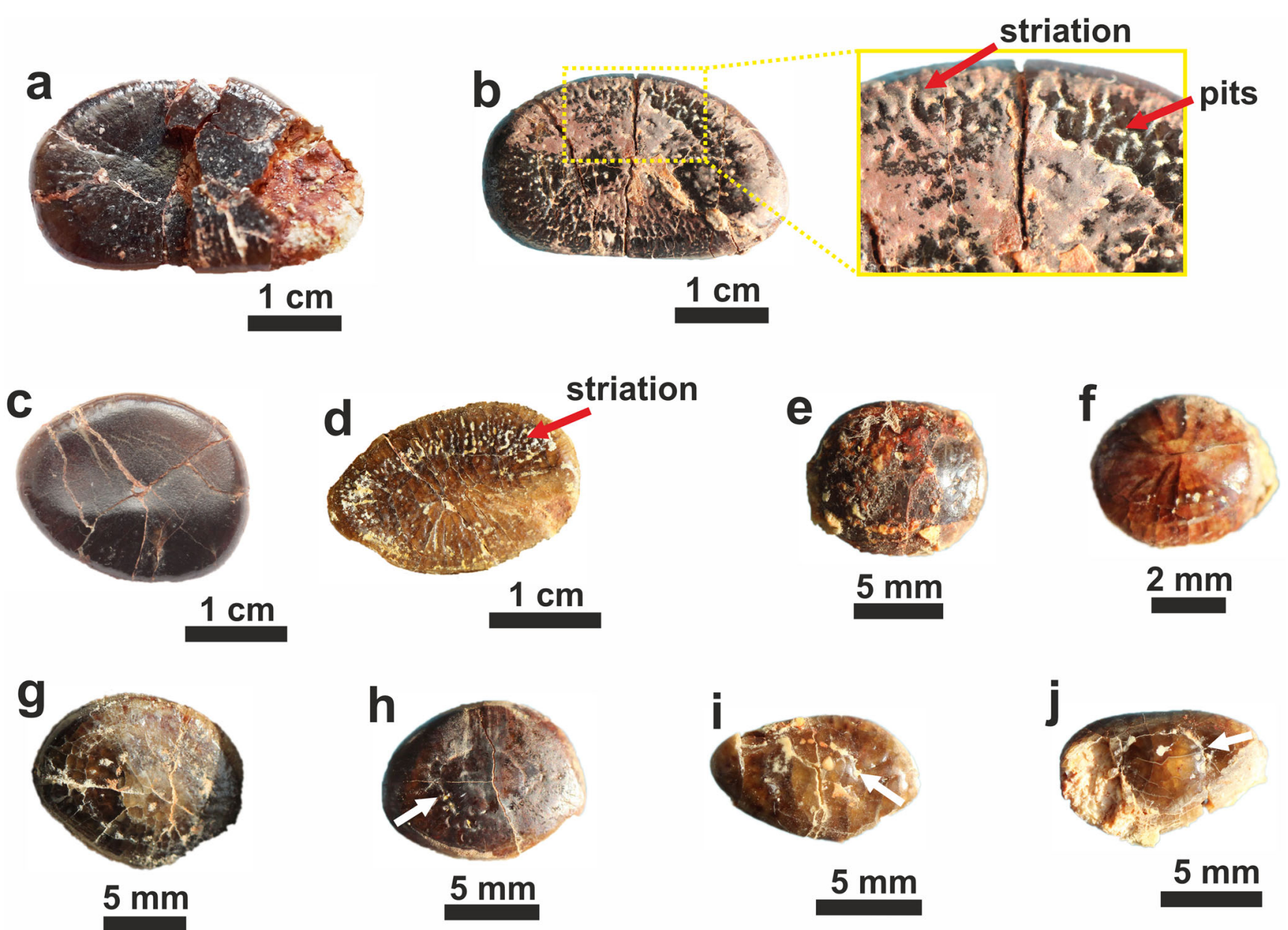

Fig. 5 Isolated teeth of Cyamodus sp. from Somssich Hill, Villány Mountain. a MTM VER 2013.15. isolated dentary tooth. b MTM VER 2019.28. isolated tooth and its enlarged surface. c MTM VER 2019.15. isolated palatine tooth. d MTM VER 2019.16. isolated palatine tooth. e

MTM VER 2019.43. isolated tooth. f MTM VER 2019.44. isolated tooth. g MTM VER 2019.45. isolated tooth. h MTM VER 2019.46. isolated tooth. i MTM VER 2019.56. isolated tooth. j MTM VER 2019.57. isolated tooth. The white arrows show the circle bulge on the crown

palatine teeth of Cyamodus muensteri Agassiz, 1839 (BSP As VII 1210) and Cyamodus rostratus Münster, 1839 (SMNS 17403) are slightly pointed mesiodistally, but they are more convex transversally compared with the Villány specimens. Cyamodus kuhnschnyderi Nosotti et Pinna, 1993 and Cyamodus hildegardis Peyer, 1931b have nearly circular palatine teeth. The teeth of these four species are much more robust and have higher tooth crowns than the Villány specimens. Tooth crowns are usually more or less worn in most Cyamodus species; thus, the original morphology can be studied only in a few specimens. Radial striations on the palatine teeth, as seen on the Villány teeth, can be observed in C. kuhnschnyderi, C. rostratus and C. hildegardis, while in C. muensteri, there is no ornamentation. On the unworn teeth of C. kuhnschnyderi (SMNS 15855) and Cyamodus sp. (SMF $\mathrm{R}$ 4039), there is a longitudinally deep, short groove in the middle of the crown from which wrinkles extend radially towards both ends of the crown. Furthermore, the whole occlusal surface of the teeth is covered by strong, deep striations.
Therefore, the Villány palatine teeth are distinct from those of C. kuhnschnyderi because they have only fine striations and a small bulge in the middle of the crown. Such a bulge can be observed, for example, in younger individuals of C. hildegardis (e.g. PIMUZ T58).

Maxillary (or first palatine) teeth (the third morphotype) have similar circular or button-like appearance in all Cyamodus species (e.g. Rieppel 2001), similar to the Villány specimens. In this tooth type, a bulge also appears in C. hildegardis and two Cyamodus sp. (SMF R 4039 and SMF R 4040) specimens. Dentary teeth of Cyamodus are morphologically similar to palatine and maxillary teeth; however, their last teeth are slightly more elongated mesiodistally, a condition also seen in the Villány teeth. The bean-shaped, enlarged dentary tooth is similar to Cyamodus sp. from Slovenia (Buffetaut and Novak 2008), but the Hungarian form does not have an elongate ("bowl shaped") depression on the occlusal surface. MTM VER 2019.56. and MTM VER 2019.57. with their more elongated and pointed shape are 
distinguished from all Cyamodus species and similar shape can only be observed in the case of the maxillary teeth of Protenodontosaurus.

The cyamodontid form from the Villány Mountains is comparable with the genus Cyamodus because of some tooth crown morphological features (e.g. bulge and striations on the crown, the button-like appearance of the maxillary teeth). However, due to the dental wear, the morphology cannot be examined in most species, and the shape of the teeth is varied within the species. Therefore a more precise (species-level) identification is not possible, and based on the teeth, the abovementioned placodont remains from Villány are identified as Cyamodus sp. in the present paper.

Cyamodontoidea indet.

\section{Description}

Dermal armour fragments: Eleven fragments can be referred to the dermal armour. They are covered by purple crust (caused by diagenetic processes), and the external bone surfaces of the plates are usually pitted. The greatest length of the most complete dermal armour fragment (MTM PAL 2019.230 .1 .) is $9.9 \mathrm{~cm}$. It is composed of various small $(0.9 \times 0.9 \mathrm{~cm}$ length-width) pentagonal elements (Fig. 6a) that have a similar thickness of app. $0.3 \mathrm{~cm}$. The whole fragment is slightly bent, but this might be due to diagenetic processes.

In case of the $7.9 \mathrm{~cm}$ long MTM PAL 2019.231.1. armour fragment, four $(2.25 \times 2.5 \mathrm{~cm}$ length-width $)$ hexagonal or heptagonal flat elements are fused (Fig. 6b, c). One of these elements is surrounded by smaller $(1 \times 0.7 \mathrm{~cm}$ length-width $)$ elements with similar shape. The polygonal outline of the individual armour plates can be observed only from one side of the armour blocks that is most probably the ventral side. The dorsal side of the dermal armour block has a fine but recognisable ornamentation (schematic drawing of Fig. 6b). Centrally, they bear a shallow, most probably anteroposteriorly oriented crest or protuberance from where shallow furrows extend radially towards the margin of the elements. No ornamentation can be observed on the elements that would extend onto the neighbouring polygonal armour plates.

The MTM VER 2019.100. associated block consists of two intact hexagonal flat elements with similar size and a bigger fragmented one (Fig. 6d). The thickness is $3 \mathrm{~mm}$. The specimens MTM VER 2019.101. and the MTM VER 2019.102. are also associated blocks, but they are not well preserved, and the shape of the individual elements is not determinable (Fig. $6 e, f)$.

Five isolated fragments (MTM PAL 2019.232.1., MTM VER 2019.103., MTM VER 2019.104., MTM VER 2019.105., MTM VER 2019.106.) with various sizes bear two parallel ridges (with app. $1 \mathrm{~mm}$ height) dorsally in the middle of the plate, where the distance is $2-5 \mathrm{~mm}$ between the ridges (Fig. $6 \mathrm{~g}-\mathrm{j}$ ), and there is one fragment without parallel ridges (MTM VER 2019.107.; Fig. 6k). Their original shape cannot be determined; their thickness is app. $2 \mathrm{~mm}$. The ornamentation can be observed as shallow furrows on one of their sides (probably dorsal, similarly to MTM PAL 2019.232.1.). MTM VER 2019.108. differs from the other isolated armour plates because it has a circular shape and it is convex dorsally and concave ventrally. It also has two parallel ridges on its dorsal surface.

Comparisons: The relatively flat dorsal surface of the dermal armour fragments differs from the conical or pyramidal armour elements of Placochelys placodonta, where this type of elements are ornamented with 8-10 ridges and grooves (Kormos 1917). However, on the edge of the carapace fragment of Placochelys, there are also small, flat, polygonal elements similar to the one from Villány. Psephosaurus suevicus FRAAS, 1896 has also morphologically similar conical armour elements, as does Placochelys, too, and these elements are polygonal or rounded in ventral view in both taxa (Rieppel 2002a). However, Psephosaurus has flattened, pentagonal or hexagonal elements varying in size $(15-25 \mathrm{~mm})$, and these elements are ornamented with radial furrows. Some armour plates described as Psephosaurus also have a depression in the middle of the dorsal side (e.g. SMNS 2091). In contrast, the Villány armour plates have no such conical ornamentation but the furrows are similar to Psephosaurus. Flattened armour plates are not present in Cyamodus kuhnschnyderi and it has enlarged, keeled, octagonal armour plates with rectangular dorsolateral ridge, but pyramidal- and triangular-shaped elements also occur (Rieppel 2002a). In the case of C. hildegardis, the tubercular armour plates are only known in two dimensions, laying on the lateral margin of the carapace (Rieppel 2002a). C. hildegardis has ovoid, keeled elements (e.g. PIMUZ T58; e.g. Pinna 1980; Scheyer 2010), and some pits can be observed on the dorsal side, while ventrally it is rough and convex.

The carapace of Cyamodus orientalis WANG ET AL., 2019 and Psephoderma alpinum is built up by flat elements (Mazin and Pinna 1993; Rieppel 2002a; Wang et al. 2019). The polygonal, irregular-shaped and different-sized specimens from Villány are distinguishable from the regular hexagonal (sometimes pentagonal) armour plates of Psephoderma and from the hexagonal, but irregular-shaped and -sized armour plates of $C$. orientalis. In Psephoderma, three rows of armour plates have slightly bending parasagittal crests extending across the whole dorsal armour (Mazin and Pinna 1993; Rieppel 2002a). Cyamodus orientalis has no such crest (Wang et al. 2019). In contrast, the individual Villány armour plates have two parallel ridges that are sharper, lower and narrower than the crests in Psephoderma. C. orientalis has a shallow radial structure dorsally to form a polygonal 


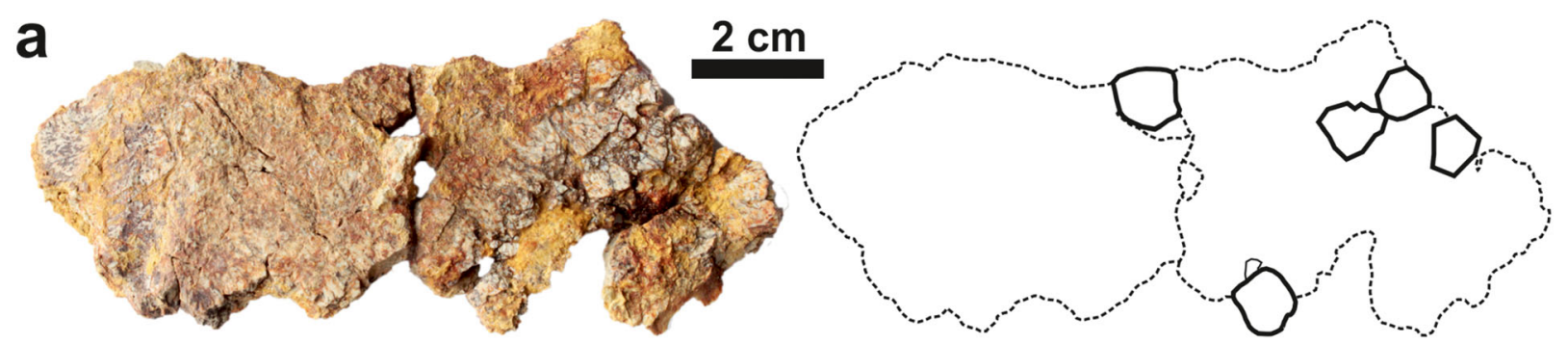

b
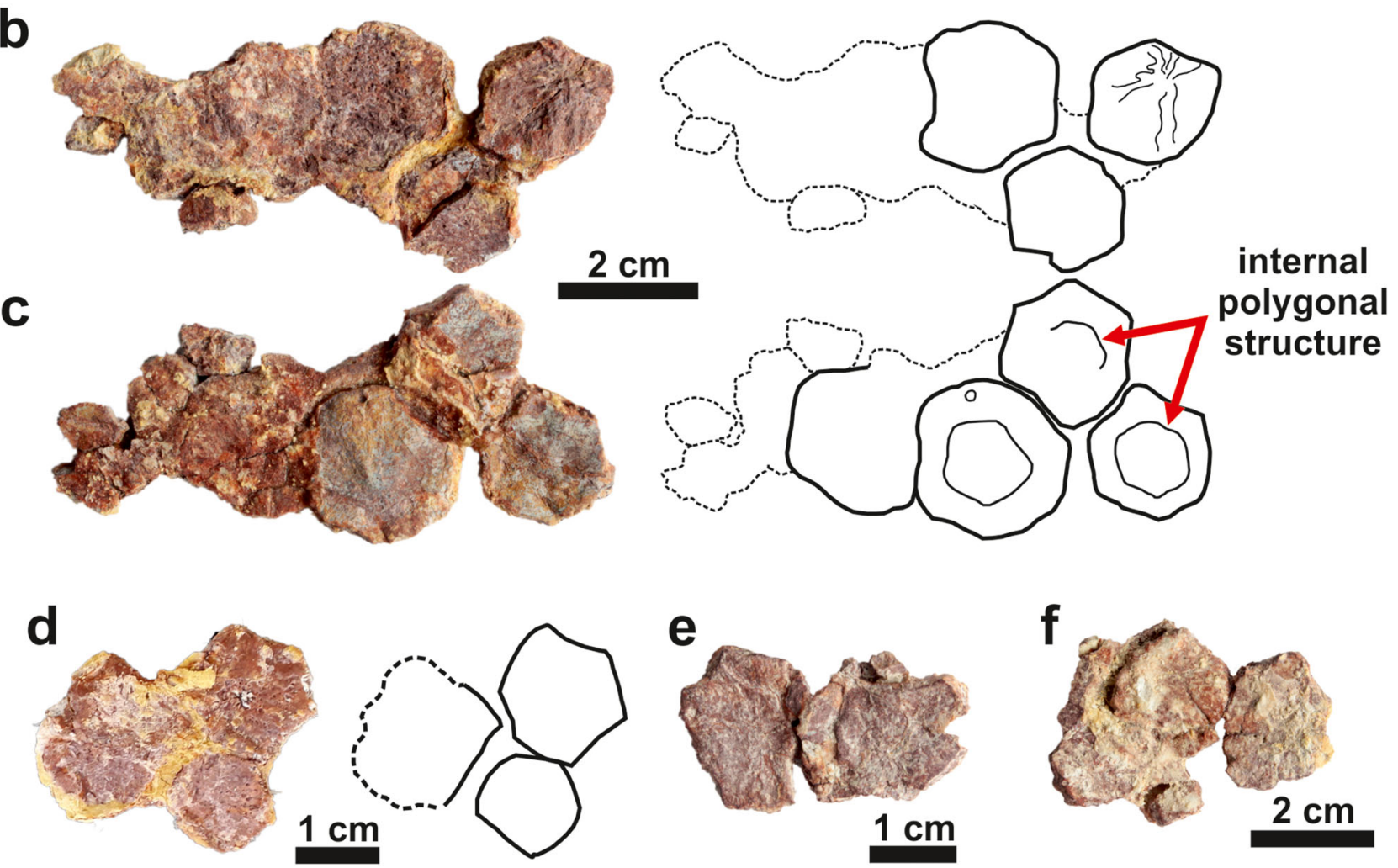
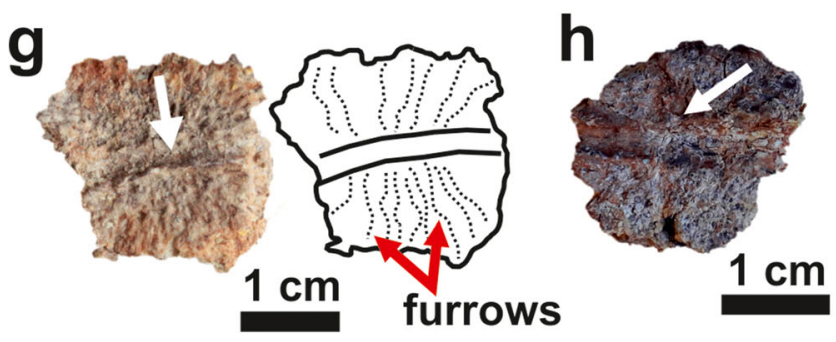

Fig. 6 Cyamodontoidea indet. armour fragments from Somssich Hill, Villány Mountain. a MTM PAL 2019.230.1. associated armour fragment in dorsal view and its schematic drawing. b MTM PAL 2019.231.1. associated armour fragment in dorsal view and its schematic drawing $\mathbf{c}$ and in ventral view with schematic drawing. d MTM VER 2019.100. associated armour fragment with schematic drawing. e MTM VER 2019.101. associated armour fragment. f MTM

texture inside each armour plate, while on the dorsal side of the Psephoderma armour plates, a shallow, circular depression or emmersion can be observed that is surrounded by a circular groove (e.g. PIMUZ A500) and deep furrows
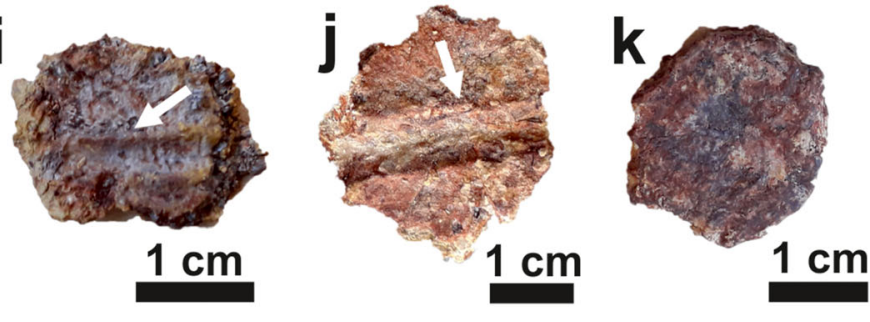

VER 2019.102. associated armour fragment. g MTM PAL 2019.232.1. isolated armour fragment and its schematic drawing. h MTM VER 2019.103. isolated armour fragment. i MTM VER 2019.104. isolated armour fragment. j MTM VER 2019.105. isolated armour fragment. $\mathbf{k}$ MTM VER 2019.107. isolated armour fragment. White arrows show the two parallel ridges

appear on the entire dorsal surface of some of the armour plates (e.g. BSP 1963 VI 176 and BSP 1966 XXIX 32).

The armour plates of the Villány placodont are similar in shape to those of Psephoderma alpinum and Cyamodus 
orientalis. The two parallel ridges (Fig. $6 \mathrm{~g}-\mathrm{j}$ ) on the Villány specimens appear to be a unique feature among known placodonts. The species-level identification of these dermal armour is, however, quite difficult due to the poor preservation of armour plates of the genus Cyamodus, as well as to their scarcity in the fossil record. In addition, some features, such as the flat, polygonal morphology and the shallow radially oriented ridges on the dorsal surface of the armour plates appear in several species. Thus, we tentatively refer these armour plates here as Cyamodontoidea indet. until more complete material will be available.

Placodontia indet.

\section{Description}

Vertebrae: The four vertebral centra are preserved without neural arches and are slightly compressed (Fig. 7a-f). The vertebral centrum is slightly elongated (length/width ratio varies between $2.5 / 2.25 \mathrm{~cm}=1.11$ and $1.35 / 0.6 \mathrm{~cm}=2.25$ ), amphicoelous and bears a depression laterodorsally. The largest specimen (MTM VER 2019.120.) is $2.5 \mathrm{~cm}$ long and 2.25 $\mathrm{cm}$ wide with massive appearance probably representing a dorsal vertebra (Fig. $7 \mathrm{a}-\mathrm{c})$. A smaller $(1.35 \mathrm{~cm} \times 0.6 \mathrm{~cm})$ elongated centrum (MTM VER 2019.123.) is interpreted as a caudal vertebra (Fig. 7f) because this type of vertebra in placodonts is more elongated and slender, unlike the other type.

Humerus: The 5.8-cm-long right humerus (MTM VER 2013.11.) has a slight curvature (Fig. 7g-i). The distal articular surface is lateromedially extended and dorsoventrally flattened granting a fan-like appearance to it. The midshaft area consists of a slightly concave preaxial margin and a more concave postaxial margin. The dorsal side is almost completely straight in lateral view, while the ventral side is only curved proximally because of the protruding ridge.

Comparisons: The humerus referred here to placodonts (MTM VER 2013.11.) differs from that of Paraplacodus because the latter has the same width of the proximal and distal heads (Rieppel 2000; Klein and Hagdorn 2014). Its preaxial side is slightly concave or straight similarly to that of Placodus and Cyamodus (Rieppel 1995; Klein and Hagdorn 2014), but the fan-like widening of the distal head of the humerus MTM VER 2013.11. is not present in these forms. Furthermore, the humeri of Placodus and Cyamodus have similar morphology, and distinguishing them is based on size and stratigraphy (Vogt 1983; Rieppel 1995).

The vertebrae of the Villány placodont with amphicoelous centra are distinguishable from the slightly amphicoelous or platycoelous vertebrae of nothosaurs (Rieppel and Wild 1996). A depression laterally on the dorsal side of Villány specimens can be observed in placodonts, for example in the case of SMNS 54547 Placodus gigas and SMNS 59825
Cyamodus. Vertebral centra are not diagnostic at species level, but the neural arches can be useful for taxonomic purposes (Klein and Scheyer 2014; During et al. 2017).

Since non-armour plate postcranial elements of placodonts are usually difficult to diagnose at generic or species level, thus these elements are referred to as Placodontia indet. until more complete material will be available.

Cyamodontoidea Nopcsa, 1923

Placochelyda Romer, 1956

Placochelys Jaekel, 1902a, 1902b

Placochelys placodonta Jaekel, 1902a, 1902b

Material: right dentary fragment (MBFSZ Ob.2323, Vt.3), two isolated teeth (MBFSZ Ob.2323, Vt.3)

Remarks: Though inventoried under the same number, these specimens do not belong to the either the holotype or paratype (see above in Material and methods)

Age: Late Triassic, Carnian

Locality: Jeruzsálem Hill, Bakony Mountains (Transdanubian Range) (Jaekel 1902b, 1907) (Fig. 1)

Stratigraphic range and facies: Veszprém Marl Formation built up of grey clay marl, marl or silty marl with carbonate interbeddings (Fig. 2). The Veszprém Marl Formation represents a basin and slope facies deposited in fragmented subbasins between carbonate platforms, with limited connections to the open sea (Csillag and Haas 1993). Tamás Budai (pers. comm. to A.Ö.) suggested that the rocks embedding the Placochelys finds from Veszprém might not have belonged to the Veszprém Marl Formation but rather to the overlying (also Carnian) Sándorhegy Limestone Formation. Both formations represent different phases of the filling up of the basin, with the Sándorhegy Limestone Formation being the later in this process, deposited in a more shallow environment, with a transition from mainly terrigenous to dominantly carbonate sedimentation.

This argument still needs to be addressed but is out of the scope of the present paper.

\section{Description}

Dentary: A 3.5-cm-long right dentary fragment (MBFSZ Ob.2323, Vt.3) has the last enlarged tooth (Fig. 8a-c). The part of the bone under the tooth is preserved to the base of the Meckel's groove, the splenial is missing. The anterior part of the Meckelian canal is triangular-shaped in cross-section. The tooth is brownish, only slightly worn and well preserved; thus, the original morphology of the occlusal surface can be studied. The tooth has an elongated oval shape (length/ width $=1.6$ ), and it is more narrow mesially (Fig. 8c). In occlusal view, the labial side is more convex than the lingual one. The tooth crown consists of two distinct domed surfaces separated by a mesiodistal depression. Of these 

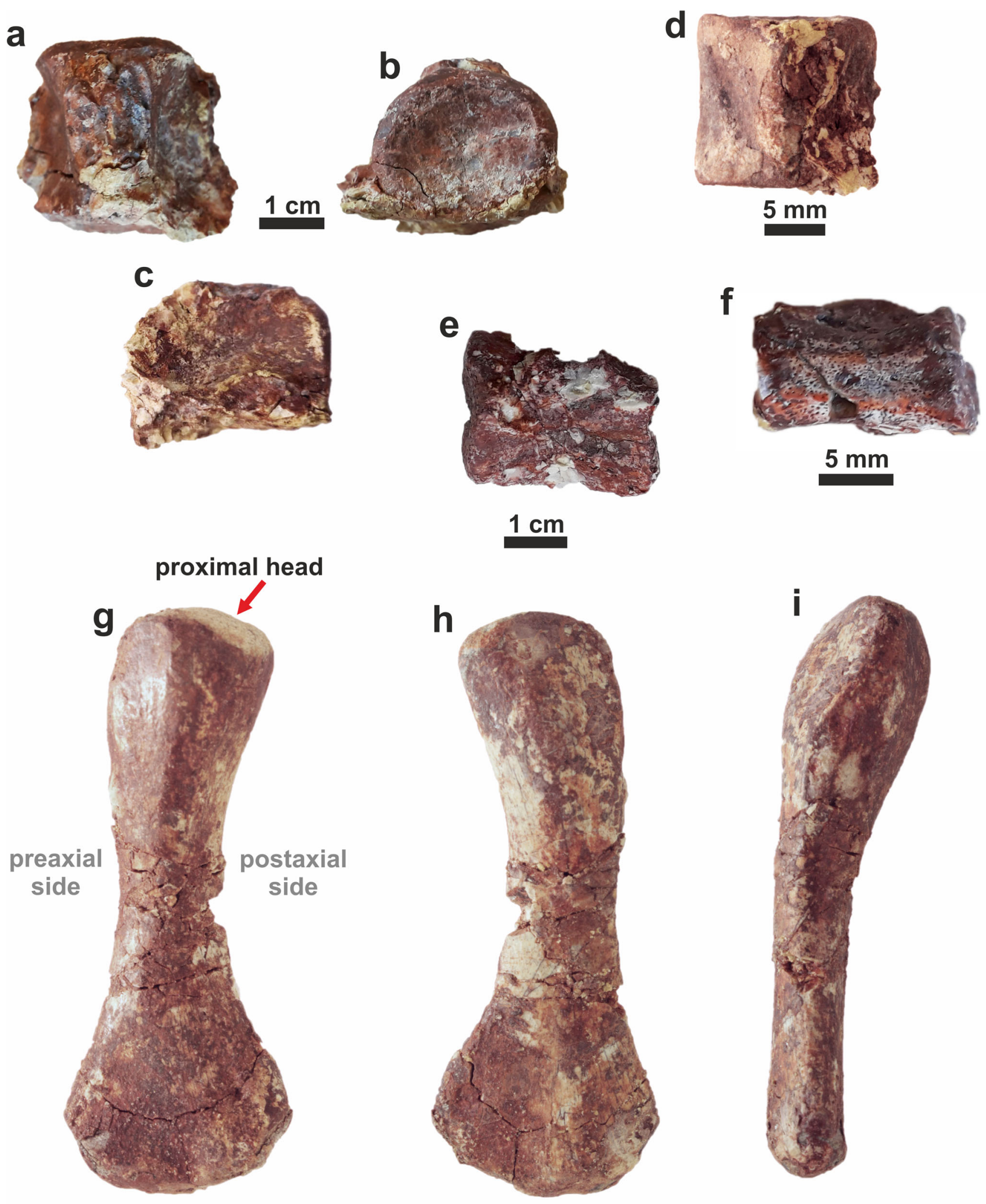

\section{$1 \mathrm{~cm}$}

Fig. 7 Placodontia indet. postcranial elements from the late Ladinian of Villány. a MTM VER 2019.120. vertebral centrum in dorsal, b anterior or posterior and $\mathbf{c}$ lateral view. d MTM VER 2019.121. vertebral centrum in

dorsal view. e MTM VER 2019.122. vertebral centrum in dorsal view. f MTM VER 2019.123. vertebral centrum in ventral view. $\mathbf{g}$ VER 2013.11. right humerus in ventral, $\mathbf{h}$ dorsal and $\mathbf{i}$ preaxial view 
two "peaks", the labial one is lower and is situated more mesially on the crown, while the higher, lingual one rises more distally.

Isolated teeth: One isolated tooth (MBFSZ Ob.2323, Vt.3, Fig. 8d) can be identified as dentary tooth and has the same ratios (length/width $=1.61$ ) and similar morphology as the one in the mandible. This specimen is more fragmented but quite well preserved. The main difference is that there are well-visible radial striations on the entire crown which become finer basally.

There is another isolated tooth (Fig. 8e) under the same inventory number that is probably a maxillary tooth, but its more exact position cannot be determined. In occlusal view, it has a slightly elongated angular shape with a straight lingual and a convex labial side. On the lingual part of the occlusal surface, there is a crescent-shaped, mesiodistally extending depression, which has a straight lingual and a convex labial side. Inside this depression, some fine grooves run labiolingually; they seem to be slightly worn.

Comparisons: The shape of the abovementioned enlarged dentary teeth is similar to those of the holotype. The length/ width ratio is almost the same, though the isolated dentary tooth is slightly more elongated. The enlarged dentary teeth of the

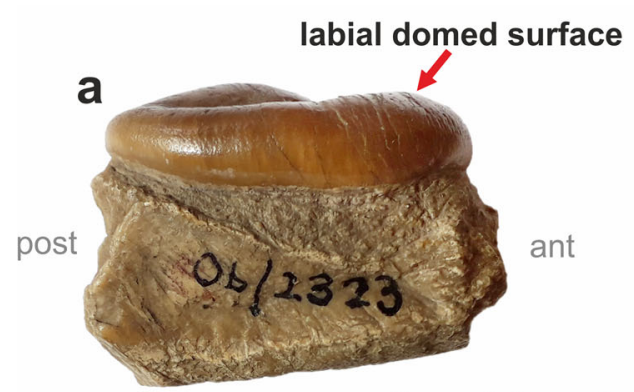

holotype are heavily worn, and the dentine is exposed in most parts of the occlusal surface. Unlike in the isolated ones, the original tooth morphology such as striations, mesiodistal depression and domed surfaces cannot be observed on the dentary teeth.

The other small isolated tooth shows similarities with the maxillary teeth of the holotype skull. The first two teeth in the maxilla have a crescent depression on the lingual side like the isolated one; however, their shape is convex both labially and lingually. The third maxillary tooth of the skull is worn and has a straight lingual side similar to the isolated maxilla tooth. The size of the isolated tooth is almost the same as the first maxillary tooth of the holotype skull.

Cyamodontoidea Nopcsa, 1923

Placochelyidae indet.

Material: fragmentary isolated tooth (MBFSZ T.1242)

Remarks: The specimen was mentioned as "Placochelys (?) palatine tooth" by Böckh and Lóczy (1912), citing Jaekel's determination and has been inventoried as such. This was later modified to Placodus sp. by an unknown person in the catalogue.

Age: Late Triassic, Norian-Rhaetian

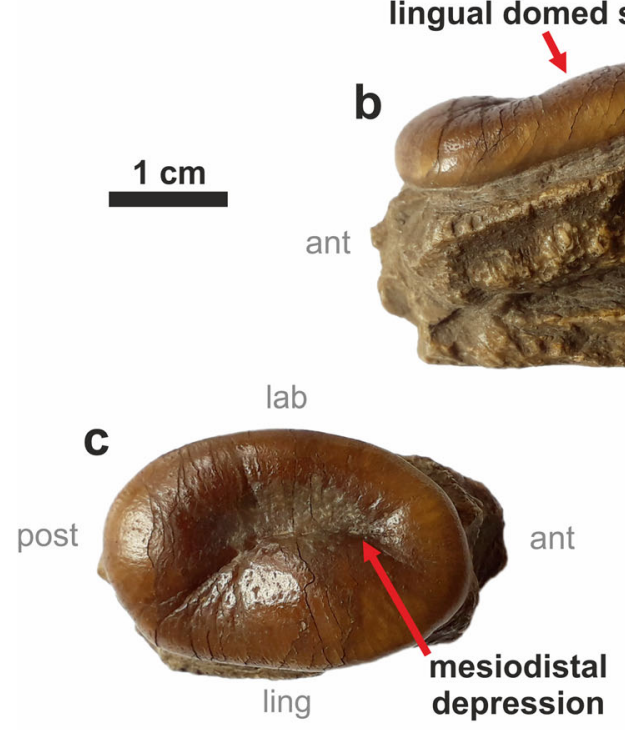

Fig. 8 Cranial remains of Placochelys placodonta from the Jeruzsálem Hill, Veszprém (Transdanubian Range). MBFSZ Ob.2323, Vt.3 right dentary fragment in a labial, b lingual and $\mathbf{c}$ occlusal view. d MBFSZ
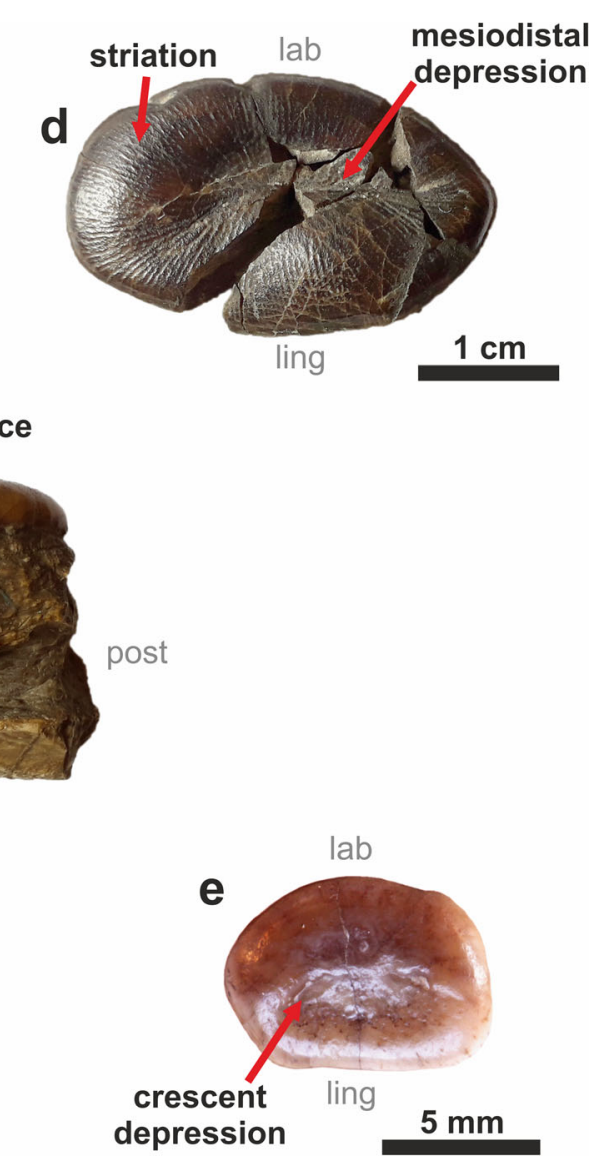

Ob.2323, Vt.3 isolated dentary tooth in occlusal view. e MBFSZ Ob.2323, Vt.3 isolated tooth in occlusal view. post posterior, ant anterior, ling lingual, lab labial 
Locality: Akasztó Hill, Keszthely Mountains (Transdanubian Range) (Fig. 1)

Stratigraphic range and facies: Kössen Formation built up by dark grey clay marl and marl, formed in a closed, oxygendepleted basin behind the Dachstein platform (Böckh and Lóczy 1912; Haas 1993; Fig. 2). Towards the platform, more and more limestone intercalations occur in the succession.

Description: The isolated tooth is a 1.8-cm-long and 1.4-cmwide fragment, which has a pointed mesial or distal side (Fig. 9a). Occlusally, most of the enamel is missing; thus, the dentine is exposed. On the intact part of the enamel, a depression can be observed, which is a worn surface. The original shape of the tooth is probably non-rectangular and elongated with a relatively low tooth crown $(0.35 \mathrm{~cm})$. Its size and shape refers to an enlarged palatine or dentary tooth.

Comparison: Because of the non-rectangular, oval or elongated shape, this tooth can be well distinguished from the teeth of placodontoids (e.g. Placodus and Paraplacodus) (Mazin 1989). A pointed side can be observed in Placochelys and Psephoderma and also in some Villány specimens, but in Psephoderma, these teeth are more pointed than in Placochelys (e.g. PIMUZ A/III4495 Psephoderma alpinum and PIMUZ A/III4493 P. alpinum). Very similar tooth fragments have been described earlier under distinct names, such as Placodus sp. (PIMUZ A/III0497), aff. Placochelys (PIMUZ A/III0879; Fig. 9b) and Placochelys stoppanii (BSP As I 1468; a synonym of Psephoderma alpinum; Fig. 9c). Based on the age (Norian-Rhaetian) and the lithostratigraphy (Kössen Formation), the tooth from Rezi might have belonged to Psephoderma; however, this fragment does not allow a genus-level identification.

\section{Palaeobiogeographical and biostratigraphical implications}

Placodonts inhabited three main areas during the Triassic: the epicontinental Muschelkalk sea (i.e. the sedimentary basin of the Germanic Triassic), the carbonate platform of the northwestern Tethys and the northeastern Tethyan realms (e.g. Rieppel 2000). These habitats were mainly characterised by different taxa (e.g. Pinna 1990; Rieppel and Hagdorn 1997); however, the typical Muschelkalk/northwestern Tethyan genera Cyamodus and Placodus appear also in the northeastern part of the Tethys, represented by $P$. inexpectatus and C. orientalis, both described from Guizhou Province, China (Jiang et al. 2008; Wang et al. 2019). Due to the transgression at the Anisian-Ladinian boundary, connections were formed between the western European epicontinental and Tethyan areas, thereby several placodont forms could have migrated. Later during the late Ladinian and at the beginning of the Late Triassic, the extension of the Muschelkalk sea decreased and placodonts became mainly restricted to the coastal regions of
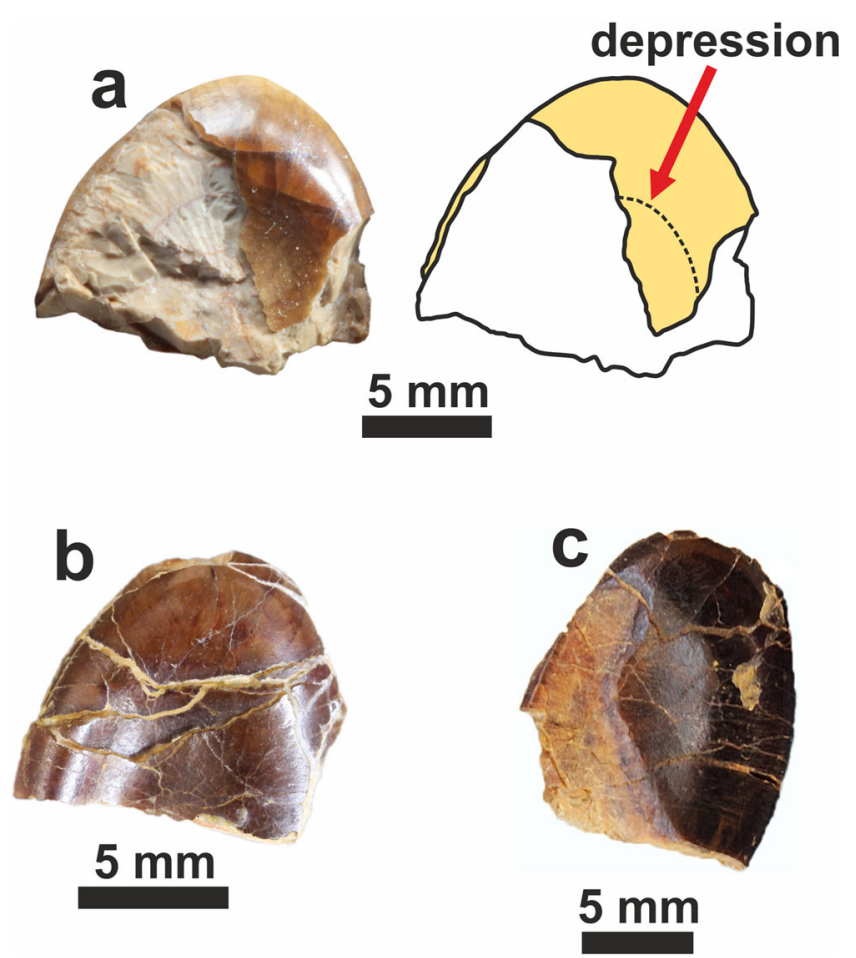

Fig. 9 a MBFSZ T.1242 Placochelydidae indet. isolated tooth from the Akasztó Hill, Rezi (Keszthely Mountain) in occlusal view and its schematic drawing. b PIMUZ A/III879 Placodus aff. Placochelys isolated tooth fragment from Arzo, (Switzerland, Pal. Inst. und Mus., Universität Zürich). c BSP As I 1468 Placochelys stoppanii isolated tooth fragment from Kotalm (Germany, Bay. Staatss. für Pal. und Hist. Geol., München)

the Tethys (an exception is the enigmatic Henodus in the Germanic Basin) (Pinna 1990).

The newly described Hungarian placodont finds from four different stratigraphic levels (upper Anisian, upper Ladinian, Carnian, Norian-Rhaetian) of two different tectonical units fit well in this biogeographical scenario and improve our knowledge on the distribution of some Middle to Late Triassic placodonts in the following points:

1) Paraplacodus broilii were described from the AnisianLadinian boundary of Monte San Giorgio (Switzerland) and Besano Formation (Italy). The P. broilii maxilla from Felsőörs, Balaton Highland is late Anisian in age (Vörös et al. 2003). Since the Balaton Highland within the Transdanubian Range was part of the Mediterranean Apulian microplate together with some Alpine tectonical units (e.g. Monte San Giorgio of the Southern Alps) in the Tethyan realm (Csontos and Vörös 2004), the appearance of the species in the Hungarian region fits well in this scenario.

2) Cyamodus appears both in the Triassic of the Germanic Basin and the Alpine region and southern China. C. hildegardis appears at the Anisian-Ladinian boundary (Kuhn-Schnyder 1960; Pinna 1980, 1990). C. rostratus 
and C. muensteri was described from the upper Anisian; C. kuhnschnyderi from the lower Ladinian (Nosotti and Pinna 1993; Rieppel and Hagdorn 1999), Cyamodus sp. from the upper Ladinian of Toško Čelo (Slovenia; Buffetaut and Novak 2008) and Rio Fus (Italy; Dalla Vecchia 1994); and from the Upper Muschelkalk of Bayreuth (Germany; Drevermann 1924). A fragmented skull of Cyamodus sp. is mentioned from the lower Carnian of Fusea (Italy; Rieppel and Nosotti 2001), but the exact determination of the specimen is uncertain.

The Cyamodus sp. from Villány is quite close in age to the Slovenian Cyamodus sp. specimen, the latter being presumably lower Carnian (Buffetaut and Novak 2008). Cyamodus disappeared from the Germanic Basin during the lower Ladinian because the Muschelkalk sea retreated and instead the upper Ladinian non-marine Lettenkeuper facies was deposited (Pinna 1990). In contrast to the Germanic Basin, marine conditions were still present in the Villány Mountains during the upper Ladinian, as it was the case in the region of Toško Čelo as well (Buffetaut and Novak 2008). Previously, it was assumed that the last representatives of Cyamodus are late Ladinian occurrences from Toško Čelo but a recently described species, C. orientalis from the lower Carnian of Guizhou Province of Southwest China (Wang et al. 2019), expands its stratigraphic range to the early Late Triassic and its spatial occurrence from the western Tethys to the eastern Tethys. The Cyamodus sp. from Villány is one of the last representatives of the genus along the northern Tethyan margin, besides the Slovenian specimen. It is also important that placodont remains are rather scarce in the late Middle Triassic of Europe; therefore, the Villány locality fills a gap between lower Ladinian (Cyamodus kuhnschnyderi) and Carnian forms (Placochelys placodonta, Henodus chelyops, Protenodontosaurus italicus, Sinocyamodus xinpuensis and Psephochelys polyosteoderma) in this region. In addition, placodont fossils from Villány with their suggested late Ladinian age represent a new, unsampled area along the northern coast of the Tethys and play an important role in the biogeography of placodonts.

\section{Conclusion}

Middle and Late Triassic placodont forms are known in Hungary from two different tectonic units and four stratigraphic levels at four localities. The Alpine-type Transdanubian Range Unit contains the oldest (late Anisian) Hungarian placodont, Paraplacodus broilii from Felsöörs (Balaton Highland). This specimen is similar in age to the occurrences of the species in Monte San Giorgio (Switzerland) and Besano Formation (Italy); moreover, these sites had similar palaeogeographical position in the Anisian in the Tethyan realm.

Late Triassic forms are also found in the Transdanubian Range Unit. Besides the well-known Carnian Placochelys finds from Veszprém, placodonts are known from the Norian-Rhaetian Kössen Formation (Keszthely Mts.) as the geologically youngest occurrence of the group in Hungary. This tooth fragment can be identified only as Placochelyidae indet. because its fragmentary nature does not allow more precise identification.

The Villány locality, situated on the other, Germanic Basin-type tectonic unit (Villány-Bihar Unit) yielded the rich Cyamodus sp. material from the late Ladinian. This taxon cannot be unequivocally assigned to known Cyamodus species because the morphology of the teeth shows some differences compared to the other taxa. Furthermore, the armour material also differs from the armour of known placodont forms; thus, these elements were only identified as Cyamodontoidea indet. The Villány Cyamodus is similar to the Slovenian Cyamodus sp. and both are regarded as being the last representatives of the genus in the European Triassic. In addition, the Villány site is considered as a gap locality because of the rarity of Ladinian placodont occurrences.

Acknowledgements We are grateful to $\mathrm{P}$. Tárnoki for making his private collections available for study, to the Hungarian Natural History Museum for the availability of the Villány material and to the Mining and Geological Survey of Hungary for granting access to Placochelys placodonta and Placochelyidae indet. We also thank R. Kalmár and J. Magyar for the preparation of the Villány fossils. We are also grateful to the following persons for access of their comparative collection: Dr. O. Rauhut (Bayerische Staatssammlung für Paläontologie und Historische Geologie Munich), Dr. I. Werneburg (Geologisch-Paläontologisches Institut, Universität Tübingen), Dr. C. Klug and B. Scheffold (the Paläontologisches Institut und Museum, Universität Zürich), Dr. R. Brocke and G. Riedel (Senckenberg Forschungsinstitut und Naturmuseum Frankfurt) and Dr. E. Maxwell (Staatliches Museum für Naturkunde Stuttgart). The useful advice of T. Budai and Zs. Kercsmár is greatly appreciated. The advice of L. Bontó about the history of Placochelys discoveries of Laczkó is acknowledged. We are thankful to James Neenan and the anonymous reviewer for their constructive suggestions and positive comments.

Funding information Open access funding provided by Eötvös Loránd University (ELTE). This research was funded by National Research, Development and Innovation Office of Hungary (NKFIH K116665), the Eötvös Loránd University and the Hungarian Natural History Museum, as well as by the FKFO-10 project of the Mining and Geological Survey of Hungary. TMS received support from the Swiss National Science Foundation (grant no. 31003A_179401).

\section{Compliance with ethical standards}

Conflict of interest The authors declare that they have no conflict of interest.

Open Access This article is licensed under a Creative Commons Attribution 4.0 International License, which permits use, sharing, adaptation, distribution and reproduction in any medium or format, as long as you give appropriate credit to the original author(s) and the source, 
provide a link to the Creative Commons licence, and indicate if changes were made. The images or other third party material in this article are included in the article's Creative Commons licence, unless indicated otherwise in a credit line to the material. If material is not included in the article's Creative Commons licence and your intended use is not permitted by statutory regulation or exceeds the permitted use, you will need to obtain permission directly from the copyright holder. To view a copy of this licence, visit http://creativecommons.org/licenses/by/4.0/.

\section{References}

Agassiz, L. (1833-1843). Recherches sur les Poissons fossiles. Neuchatel et Soleure.

Böckh, J., \& Lóczy, L. (1912). Nehány rhaetiai korú kövület zalavármegyei Rezi vidékéről és újabb ottani gyüjtések eredménye. In L. Lóczy (Ed.) A Balaton tudományos tanulmányozásának eredményei. A Balaton tudományos tanulmányozásának eredményei. I. kötet. A Balatonnak és környékének fizikai földrajza. 1. rész. A Balaton környékének földrajzi leírása, orografiája és geologiája. Függelék: A Balatonmellék palaeontológiája 2. kötet. VII. fejezet (pp. 1-8). Budapest: A Magyar Földrajzi Társaság Balaton-Bizottsága.

Bontó, L. (2019). A mi kavicsfogúnk. Placochelys placodonta, a Veszprémben felfedezett kavicsfogú álteknős. Veszprémi Szemle, 21(2) (53), 7-64.

Botfalvai, G., Győri, O., Pozsgai, E., Farkas, I., Sági, T., Szabó, M., \& Ösi, A. (2019). Sedimentological characteristics and paleoenvironmental implication of Triassic vertebrate localities in Villány. Geologica Carpathica, 70(2), 135-152. https://doi.org/10. 2478/geoca-2019-0008.

Buffetaut, E., \& Novak, M. (2008). A cyamodontid placodont (Reptilia: Sauropterygia) from the Triassic of Slovenia. Palaeontology, 51(6), 1301-1306. https://doi.org/10.1111/j.1475-4983.2008.00819.x.

Chaves, C. D. M., Ortega, F., \& Pérez-García, A. (2018). A new placodont from the upper Triassic of Spain provides new insights on the acquisition of the specialized skull of Henodontidae. Papers in Palaeontology, 4(4), 567-576. https://doi.org/10.1002/spp2.1218.

Cope, E. D. (1871). The systematic arrangement of the Reptilia. Proceedings of the American Association for the Advancement of Science, 19, 226-247.

Crofts, S. B., Neenan, J. M., \& Scheyer, T.M. (2015). Changes in placodont tooth morphology and replacement. The Society for Integrative and Comparative Biology, Annual Meeting (West Palm Beach, Florida, USA) Abstract Book, 71.

Csillag, G., \& Haas, J. (1993). Veszprémi Márga Formáció. In G. Császár (Ed.) Magyarország Litosztratigráfiai Alapegységei. Triász (pp. 6064). Magyar Állami Földtani Intézet: Budapest.

Csontos, L., \& Vörös, A. (2004). Mesozoic plate tectonic reconstruction of the Carpathian region. Palaeogeography, Palaeoclimatology, Palaeoecology, 210, 1-56 0.1016/j.palaeo.2004.02.033.

Dalla Vecchia, F. M. (1994). Reptile remains from the Middle-Upper Triassic of Carnic and Julian Alps (Friuli-Venezia Giulia, Northeastern Italy). Gortania: Atti del Museo Friulano di Storia Naturale, 15, 49-66.

Drevermann, F. (1924). Schädel und Unterkiefer von Cyamodus. Abhandlungen der Senckenbergischen Naturforschenden Gesellschaft Frankfurt, 38(4), 291-309.

During, M., Voeten, D. F. A. E., Schulp, A. S., \& Reumer, J. W. F. (2017). A possible Pararcus diepenbroeki vertebra from the Vossenveld Formation (Triassic, Anisian), Winterswijk, the Netherlands. Netherlands Journal of Geosciences / Geologie en Mijnbouw, 96, 63-68. https://doi.org/10.1017/njg.2016.7.
Fraas, E. (1896). Die schwäbischen Trias-Saurier. Versammlung der Deutschen Geologischen Gesellschaft in Stuttgart, 1-18.

Haas, J. (1985). Balaton-felvidék, Felsőörs, Forrás-hegy: Felsőörsi Mészkő Formáció. In Magyarország geológiai alapszelvényei 37 (pp. 1-8). Budapest: Magyar Állami Földtani Intézet.

Haas, J. (1993). A Kösseni-medence kialakulása és fejlődése a Dunántúliközéphegységben. Földtani Közlöny, 123(1), 9-54.

Haas, J. (2001). Geology of Hungary. Budapest: Eötvös University Press.

Huene, F. v. (1931). Ergänzungen zur Kenntnis des Schädels von Placochelys und seiner Bedeutung. Geologica Hungarica, Series Palaeontologica, 9, 1-18.

Huene, F. v. (1936). Henodus chelyops, ein neuer Placodontier. Palaeontographica A, 84, 99-148.

Jaekel, O. (1901). Reste eines neuen Placodontiden aus dem unteren Keuper von Veszprém am Plattensee in Ungarn. Zeitschrift der Deutschen Geologischen Gesellschaft, 53, 56-57.

Jaekel, O. (1902a). Ueber ein zweites Exemplar von Placochelys in Ungarn. Zeitschrift der Deutschen Geologischen Gesellschaft, 54, 111.

Jaekel, O. (1902b). Ueber Placochelys n.g. und ihre Bedeutung für die Stammesgeschichte der Schildkröten. Neues Jahrbuch für Mineralogie. Geologie und Paläontologie, 1, 127-144.

Jaekel, O. (1907). Placochelys placodonta aus der Obertrias des Bakony. In L. Lóczy (Ed.) Resultate der wissenschaftlichen Erforschung des Balatonsees. I. Band. Physische Geographie des Balatonsees und seiner Umgebung. 1. Theil. Geographische Beschreibung der Balatonsee-Umgebung, sammt deren Orographie und Geologie. Paläontologische Anhang (pp. 1-90). Budapest: BalatonseeCommission der Ungarischen geographischen Gesellschaft.

Jiang, D.-Y., Motani, R., Hao, W.-C., Rieppel, O., Sun, Y.-L., Schmitz, L., \& Sun, Z.-Y. (2008). First record of Placodontoidea (Reptilia, Sauropterygia, Placodontia) from the eastern Tethys. Journal of Vertebrate Paleontology, 28, 904-908. https://doi.org/10.1671/ 0272-4634(2008)28[904:FROPRS]2.0.CO;2.

Klein, N., \& Hagdorn, H. (2014). Humerus morphology and histology of a new marine reptile (Diapsida) from the Muschelkalk-KeuperGrenzbonebed (Middle Triassic, Ladinian) of Southwest Germany. Palaeodiversity, 7, 23-38.

Klein, N., \& Scheyer, T. M. (2014). A new placodont sauropterygian from the Middle Triassic of the Netherlands. Acta Palaeontologica Polonica, 59, 887-902. https://doi.org/10.4202/app.2012.0147.

Kormos, T. (1917). Interessante neue Funde im Museum der Kgl. Ung. geologischen Reichsanstalt. Földtani Közlöny, 47, 336-338.

Kuhn-Schnyder. (1960). Über Placodontier. Paläontologische Zeitschrift, $34,91-102$.

Mazin, J.-M. (1989). La denture et la règion palatine des Placodontia (Reptilia, Trias). Implications phylogènètiques. Geobios, 22(6), 725-734.

Mazin, J. M., \& Pinna, G. (1993). Palaeoecology of the armoured placodonts. Paleontologia Lombarda della Società Italiana di Scienze Naturali e del Museo Civico di Storia Naturale di Milano, Nuova serie, 2, 83-91.

Meyer, H. v. (1858). Psephoderma alpinum aus dem DachsteinKalke der Alpen. Neues Jahrbuch für Mineralogie, Geognosie, Geologie und Petrefaktenkunde, 1858, 646-650.

Meyer, H. v. (1863). Die Placodonten, eine Familie von Sauriern der Trias. Palaeontographica, 11, 175-221.

Münster, G. (1839). Ueber einige merkwürdige Fische aus dem Kupferschiefer und dem Muschelkalk. Beiträge zur Petrefacten-Kunde, $1,114-121$.

Nagy, E., \& Nagy, I. (1976). A Villányi-hegység triász képződményei. Geologica Hungarica, Series Geologica, 17, 111-228.

Neenan, J. M., Klein, N., \& Scheyer, T. M. (2013). European origin of placodont marine reptiles and the evolution of crushing dentition in Placodontia. Nature Communications, 4(1621), 1-7. https://doi.org/ $10.1038 /$ ncomms 2633 . 
Nopcsa, F. (1923). Die Familien der Reptilien. In W. Soergel (Ed.) Fortschritte der Geologie und Palaeontologie (Vol. 2, pp. 1-210). Berlin: Borntraeger.

Nosotti, S., \& Pinna, G. (1993). Cyamodus kuhn-schnyderi n. sp., nouvelle espèce de Cyamodontidae (Reptilia, Placodontia) du Muschelkalk supérieur allemand. Comptes rendus de l'Académie des sciences Paris, 317(2), 847-850.

Ösi, A., Pozsgai, E., Botfalvai, G., Götz, A. E., Prondvai, E., Makádi, L., Hajdu, Z., Csengődi, D., Czirják, G., Sebe, K., \& Szentesi, Z. (2013). First report of Triassic vertebrate assemblages from the Villány Hills (southern Hungary). Central European Geology, 56(4), 297-335. https://doi.org/10.1556/CEuGeol.56.2013.4.2.

Peyer, B. (1931a). Paraplacodus broilii nov. gen. nov. sp., ein neuer Placodontier aus der Tessiner Trias. Vorlaufige Mitteilung. Zentralblatt für Mineralogie, Geologie und Paläontologie. Abteilung B: Geologie und Paläontologie, 1931, 570-573.

Peyer, B. (1931b). Die Triasfauna der Tessiner Kalkalpen III. Placodontia. Abhandlungen der schweizerischen Paläontologischen Gesellschaft, $51,1-25$.

Pinna, G. (1980). Lo scheletro postcraniale di Cyamodus hildegardis Peyer, 1931 descritto su un esemplare del Triassico medio Lombardo. Atti della Società italiana di scienze naturali e del Museo civico di storia naturale di Milano, 121(4), 275-306.

Pinna, G. (1990). Notes on stratigraphy and geographical distribution of placodonts. Atti della Società italiana di scienze naturali e del Museo civico di storia naturale di Milano, 131(7), 145-156.

Reif, W.-E., \& Stein, F. (1999). Morphogeny and function of the dentition of Henodus chelyops Huene, 1936 (Placodontia, Triassic). Neues Jahrbuch für Geologie und Paläontologie, 2, 65-80.

Rieppel, O. (1995). The genus Placodus: systematics, morphology, paleobiogeography, and paleobiology. Fieldiana:Geology, 31, 144.

Rieppel, O. (2000). Paraplacodus and the phylogeny of the Placodontia (Reptilia: Sauropterygia). Zoological Journal of the Linnean Society, 130, 635-659.

Rieppel, O. (2001). The cranial anatomy of Placochelys placodonta Jaekel, 1902, and a review of the Cyamodontoidea (Reptilia, Placodonta). Fieldiana: Geology, 45, 1-104.

Rieppel, O. (2002a). The dermal armor of the cyamodontoid placodonts (Reptilia, Sauropterygia): morphology and systematic value. Fieldiana: Geology, 46, 1-41.

Rieppel, O. (2002b). Feeding mechanics in Triassic stem-group sauropterygians: the anatomy of a successful invasion of Mesozoic seas. Zoological Journal of the Linnean Society, 135, 33-63.

Rieppel, O., \& Hagdorn, H. (1997). Paleobiogeography of Middle Triassic Sauropterygia in central and western Europe. In J. M. Callaway \& E. L. Nicholls (Eds.) Ancient Marine Reptiles (pp. 121-144). San Diego, California: Academic Press.

Rieppel, O., \& Hagdorn, H. (1999). A skull of Cyamodus kuhnschnyderi Nosotti \& Pinna 1993, from the Muschelkalk of Wasselonne (Alsace, France). Paläontologische Zeitschrift, 73(3/4), 377-383.
Rieppel, O., \& Nosotti, S. (2001). A skull of Cyamodus (Sauropterygia, Placodontia) from the Triassic of Fusea, Province of Udine, northeastern Italy. Atti della Società italiana di scienze naturali e del Museo civico di storia naturale di Milano, 142, 173-183.

Rieppel, O., \& Wild, R. (1996). A revision of the genus Nothosaurus (Reptilia: Sauropterygia) from the Germanic Triassic, with comments on the status of Conchiosaurus clavatus. Fieldiana: Geology, 34, 1-79.

Romer, A. S. (1956). The osteology of the reptiles. Chicago: University of Chicago Press.

Scheyer, T. M. (2010). Cyamodus hildegardis Peyer, 1931 (Sauropterygia: Placodontia) from the middle Triassic of Monte San Giorgio (Ticino) - new interpretation of the postcranial skeleton. Abstractbuch der 80. Jahrestagung der Paläontologischen Gesellschaft in München, 6.-8.10.2010, Zitteliana B 29, 90.

Schubert-Klempnauer, V. H. (1975). Macroplacus raeticus n. g., n. sp. ein neuer Placodontier aus dem Rät der Bayerischen Alpen. Mitteilungen der Bayerische Staatssammlung für Paläontologie und Historische Geologie, 15, 33-55.

Segesdi, M., Ösi, A., \& Botfalvai, G. (2017). New eosauropterygian remains from the middle Triassic of Villány, Hungary. In O. Hampe, D. Schwarz, \& M. Voss (Eds.) Secondary adaptation of tetrapods to life in water, 8th International Meeting, Abstracts ( $\mathrm{p}$. 47). Berlin: Museum für Naturkunde Berlin.

Szabó, L., Botfalvai, G., \& Ösi, A. (2019). Taxonomical and palaeoecological investigations of the chondrichthyan and osteichthyan fish remains from the Middle-Late Triassic deposits of the Villány Hills (southern Hungary). Geobios, 57, 111-126.

Török, Á. (1998). Controls on development of Mid-Triassic ramps: examples from southern Hungary. In V. R. Wright \& T. P. Burchette (Eds.) Carbonate ramps (pp. 339-367). London: Geological Society.

Török, Á. (2000). Muschelkalk carbonates in southern Hungary: an overview and comparison to German Muschelkalk. In G.H. Bachmann \& I. Lerche (Eds.) Epicontinental Triassic. Zentralblatt für Geologie und Paläontologie, Teil I. 1998(9-10), 1085-1103.

Vogt, C.H. (1983). Evolutive Palökologie der Placodontier (Placodus, Henodus; Euryapsida, Trias). Ph.D. Thesis, Tübingen: EberhardKarls-University.

Vörös, A., Budai, T., Haas, J., Kovács, S., Kozur, H., \& Pálfy, J. (2003). GSSP (Global Boundary Stratotype Section and Point) proposal for the base of Ladinian (Triassic). Albertiana, 28, 35-47.

Wang, W., Li, C., Scheyer, T. M., \& Zhao, L. (2019). A new species of Cyamodus (Placodontia, Sauropterygia) from the early Late Triassic of south-west China. Journal of Systematic Palaeontology, 17, 1457-1476. https://doi.org/10.1080/14772019.2018.1535455.

Westphal, F. (1975). Bauprinzipien im Panzer der Placodonten (Reptilia triadica). Paläontologische Zeitschrift, 49(1), 97-125.

Publisher's note Springer Nature remains neutral with regard to jurisdictional claims in published maps and institutional affiliations. 